\title{
Predicting returns with financial ratios: Evidence from Indonesian Stock Exchange
}

\author{
Yohanes Indrayono ${ }^{\mathbf{a}^{*}}$
}

${ }^{a}$ Doctoral Program of Management Science, Universitas Pakuan, Bogor, Indonesia

\begin{tabular}{l}
\hline C H R O N I C L E \\
\hline Article history: \\
Received: May 12019 \\
Received in revised format: May \\
102019 \\
Accepted: June 5, 2019 \\
Available online: \\
June 6, 2019 \\
\hline Keywords: \\
Price to earnings ratio $(P / E)$ \\
Price to book value ratio $(P / B)$ \\
Stock prices \\
Decision making \\
Indonesian Stock Exchange
\end{tabular}

\section{Introduction}

There are several studies on the factors that influence stock prices and they are useful for capital market players including investors, investment advisors, analysis of capital markets and issuers. The study on stock prices is also interesting to be carried out by researchers in the fields of finance and investment. Several studies suggest that stock prices on the stock exchange are positively affected by changes in fundamental values, which include factors of profitability, growth, and dividends (Block, 1964; Shiller, 2001; Bodie et al., 2005; Lo \& Lin, 2005; Becchetti \& Di Giacomo, 2007). Das and Pattanayak (2013) introduced some interesting issues to the investors, managers, brokers as well as researchers to understand the importance of corporate fundamental factors in determining the share price movement and its effect on selection of stocks for designing an optimum portfolio. A study by De Pena et al. (2011) shows that the return on capital is an essential variable used by investors in the Spanish stock market. Allen and Yang (2003) suggested that stock price variability is the only partially explained by fundamental factors such as earnings and dividends and the rest may be due to time-varying interest rates and future excess stock returns.

* Corresponding author.

E-mail address: yindrayono@yahoo.com (Y. Indrayono)

(C) 2019 by the authors; licensee Growing Science, Canada doi: $10.5267 /$ j.msl.2019.6.003 
Shiller (1981) proposed the excess volatility hypothesis which states that changes in stock prices are very inconsistent with the movement of dividends in the future (future dividends), and stock prices are too volatile if they are associated with fundamental variables. One important factor that causes stock prices not to be in line with changes in fundamental values is the investors' behavior on the stock exchange called disposition effect which was first revealed by Shefrin and Statman (1985) and it is the development of prospect theory by Kahneman and Tversky (1979). Another study by Indrayono (2011) contributes to the existing behavioral finance literature by providing some useful insights into understanding why stock prices are less sensitive to the changes in fundamental variables in the presence of disposition effect. Various studies of the efficient market hypothesis on stock prices and stock price indexes in various capital markets reveal that certain stock exchanges yield different efficiencies. According to efficient market hypothesis, the stock price reflects the fundamental conditions of companies which could affect investors' decisions, but the empirical evidence shows that stock price is also influenced by the public's perception of the market situation (Bisen \& Pandey, 2013). In his study, Rizky (2015) argued the efficient market hypothesis which could affect investors' decisions, the fundamental conditions of firms reflect in its stock prices. His study reports empirical evidence that stock price is also influenced by the public's perception of the market situation. Global issues as external factors can influence stock prices as well as internal (enterprise performance) issues. The foreign and global issues may be important and perhaps dominant in determining the perceptions of the Indonesian stock market. By using ASEAN countries data, Munir et al. (2012) studied stock prices and efficient market hypothesis and reported that consistent with the efficient market hypothesis, stock prices of Malaysia and Thailand were non-linear series and they were characterized by a unit root process. They also reported that stock prices of Indonesia, Philippines and Singapore follow a non-linear series and stock price indices were inconsistent with the efficient market hypothesis which are stationary processes.

Bisen and Pandey (2013) provided a study on efficient market hypothesis in Indian stock market. They argued how market could be inefficient either because of not getting all the fresh news related to stocks on time or they not care about the news or disregarding to react on the newly released information because of their own psychology or sentiments.

The fundamental value known in the world of accounting is financial ratios that use numbers in the issuer's financial statements. Financial ratios using financial statement data in general can be grouped into liquidity ratios, leverages ratios, equity ratios, activity ratios, and profitability ratios. In addition, there are several market ratios which also combine market factors and company financial report data such as price to earnings ratio ( $\mathrm{P} / \mathrm{E}$ ratio) and price to book value ratio ( $\mathrm{P} / \mathrm{B}$ ratio). Most of stock markets all over the world provide earnings ratio $(\mathrm{P} / \mathrm{E}$ ratio) and price to book value ratio $(\mathrm{P} / \mathrm{B}$ ratio) data of all firms and industry average. The data are intended to be used by investors and other stock market members in their decision making.

This study intends to examine how the accounting data of price to earnings ratio (P/E ratio) and price to book value ratio $(\mathrm{P} / \mathrm{B})$ can be used to predict the stock price movements. The price to earnings $(\mathrm{P} / \mathrm{E}$ ratio) and price to book value $(\mathrm{P} / \mathrm{B})$ ratios are reliable and valid when they have significance effects on stock prices. The rest of the paper is organized as follows. The next section is devoted to the literature review, section 3 explains data and method, the section 4 analyses the result, and section 5 concludes the result of the study and the implications of the study.

\section{Literature review and hypothesis development}

For decades, several researchers in finance and accounting areas linked accounting (or accounting products) to the prices of securities markets, especially common stock market prices. Common stock market price movements have been widely used to empirically test the accuracy in the selection of accounting rules (Chambers, 1972). Nezlobin et al. (2016) argue that the price-to-earnings (P/E) and price-to-book $(\mathrm{P} / \mathrm{B})$ ratios of publicly traded firms are quoted in a variety of contexts by analysts, managers, and academic researchers. 
Basu (1977) sets the price to earnings ratio (PER) or P/E ratio by dividing market value (market value) of ordinary shares at the end of the financial reporting period (stock market prices multiplied by the number of shares outstanding) with earnings according to profit report (before extraordinary items) available to ordinary shareholders. Nezlobin et al. (2016) calculated the P/B ratio as the market value of a firm's equity divided by the book value of its equity, and it has been frequently used as a proxy for Tobin's q, which, in turn, is regarded as a determinant of future investment expenditures.

Price to earnings ratio $(\mathrm{P} / \mathrm{E})$ and price to book value $(\mathrm{P} / \mathrm{B})$ ratio are the product of historical accounting (Penman \& Reggiani, 2013), accordingly both of those are influenced by the firm's accounting policies choices. Higher future growth in the product market corresponds ceteris paribus to a higher $\mathrm{P} / \mathrm{B}$ and a higher forward P/E ratio, simply because the value of future growth opportunities is reflected in the firm's stock price but neither in earnings nor the current book value of assets. In contrast, higher past growth in investments translates into a lower $\mathrm{P} / \mathrm{B}$ ratio and a lower forward $\mathrm{P} / \mathrm{E}$ ratio under replacement cost accounting.

In terms of the investors' point of view, price to earnings ratio (PER) indicates how much costs to pay per stock by investors to get potentially periodic income (usually yearly) from the firm net profit earning which is issuing the stock. Price to book value ratio (PBV) indicates how much costs to pay per stock by investors to get potentially income from expected earnings growth not being realized by the firm which is issuing the stock. Investors must always seek the lower PER to get short term potentially gains and the lower PBV to get potentially long term gains growth from their money they invest.

The firms' objective is to maximize shareholder wealth by maximizing the value of the firm reflected by its stock price. The higher the stock price relative to its profitability and the book value, the better the performance of firm management to achieve the objective. Profitability relative to stock price is measured by how much the profitability reflected in stock price, the higher the price to earnings per share (EPS) reflected in stock price. Firm management concern is to maximize the stock price per each currency unit of earnings per share (EPS) that is price to earnings ratio $(\mathrm{P} / \mathrm{E})$ calculated by dividing stock price by its earnings per share (EPS). Book value relative to stock price is measured by how much the book value is reflected in stock price, the higher the book value per share (BVS) reflected in stock price, the higher the performance of the firms. Firm management concern is to maximize the stock book value per each currency unit of book value per share (BVS) that is price to book value ratio (PBV) which is calculated by dividing stock price by its book value per share (BVS).

Studies about stock prices and accounting measures such as earnings, book value, and other accounting data have been performed, previously. Papadaki and Siougle (2007) investigated the relationship between stock price and firm earnings across profit and loss of firms listed in the ASE and reported that there is a negative price-earnings relationship for those firms that report losses (loss firms) and a positive priceearnings relationship for those firms that report profits (profit firms).

Kwon (2009) investigated the effect of relative and incremental value relevance of book value, accounting earnings and cash flows and security prices and the result indicated that that book value was the most value relevant variable and cash flows had more value relevance than accounting earnings in all samples, subsamples and periods.

Alfaraih and Alanezi (2011), with the data from Kuwait Stock Exchange (KSE)-listed firms during the 1995-2006 period, empirically examined two valuation models based on price and earnings models. They showed that earnings and book value were, jointly and individually, positively and significantly related to stock price and stock returns. They also showed that the value relevance of earnings and book value of KSE-listed firms were higher than the findings observed in some developed and emerging countries.

Another study was on the value of the relevance of earnings and book value of equity in the Indian context by Dawar (2014). He investigated the persistence ability of accounting variables, namely, abnormal earnings, book value, accruals and cash flows over a period of time and their valuation relevance in Indian scenario. The study provided some evidence about the construct of persistence and value relevance. The study also confirmed that investors in India were fixated on earnings and failed to attend 
separately to the cash flow and accrual components of earnings while undertaking their investment decisions. Khanna (2014) analyzed the combined, individual, and incremental value relevance of accounting information produced by firms listed on the S\&P BSE-500 for FY-2006 to FY-2010, and changes therein over a period of time. Results provided sufficient evidence that accounting information is the value relevant for BSE-listed firms. The combined value relevance of accounting information represented by earnings per share and book value per share were declined while there were insignificant changes in the incremental value relevance of accounting information.

Almumani (2014) investigated the share prices for the listed banks in Amman Stock Exchange over the period 2005-2011 to identify the quantitative factors that influence it using empirical analysis of a set of independent and dependent variables. The results suggested that variables including earnings per share, book value per share, price earnings ratio, and size were significant determinants of share prices for all the banks under consideration.

Vijitha and Nimalathasan (2014) using data of Colombo Stock Exchange (CSE) provided some empirical evidence concerning value relevance of accounting information such as earnings per share (EPS), net assets value per share (NAVPS), return on equity (ROE) and price earnings ratio (P/R) to share prices (SP) of manufacturing companies. The results revealed that the value relevance of accounting information had some significant impact on share price and value relevance of accounting information was significantly correlated with share price.

Ozlen (2014) identified the effect of the selected microeconomic factors (total asset turnover ratio, debt ratio, current ratio, price to earnings ratio, net profit margin, and book value) on stock values between the second quarter of 2000 and the third quarter of 2012. The results indicated that book value had highly significant positive impact on the stock prices of all the sectors. From the above literatures review, it can be concluded that variables derive from accounting data have the impact on stock prices and it can be derived the hypothesis as follows:

$\mathrm{H}_{1}$. Earnings per share $(\mathrm{P} / \mathrm{E})$ has positive effect on stock price.

$\mathrm{H}_{2}$. Price to book value $(\mathrm{P} / \mathrm{B})$ has positive effect on stock price.

\section{Data and Method}

This study uses price to earnings per share $(\mathrm{P} / \mathrm{E})$, price to book value $(\mathrm{P} / \mathrm{B})$, and stock prices variables from the firms listed on the Indonesian Stock Exchange for 10 years starting from 2017 to 2016. Data of the firms' P/E and P/B are obtained from the Yearly IDX Statistical Book published officially by the Indonesian Stock Exchange. Data on stock prices are obtained from Yahoo Finance.

From 388 firms in 2007 and 560 in 2016 listed in Indonesian Stock Exchange and submit yearly financial, reports are selected as samples which are eligible according to the following criteria:

- Firms continued throughout the 10-year period;

- The most higher average stock trading volume during the study period;

- The stock price never reaches a minimum price which cannot decrease more.

Based on these criteria, 218 firms as samples were selected.

Price to earnings ratio ( $\mathrm{P} / \mathrm{E}$ ratio) is determined based on market prices divided by earnings per share, where EPS is profit after tax divided by the number of shares issued by the company.

Price to book value ratio ( $\mathrm{P} / \mathrm{B}$ ratio) is determined based on market price divided by the price of books per share, where BV per share is (total assets - total liabilities) divided by the number of shares issued by the company. Stock price is determined based on the average stock price at the time of closing the market day for a year, which is the sum of prices at the end of each month divided by twelve. Price to earnings ratio $(\mathrm{P} / \mathrm{E}$ ratio) and Price to book value ratio ( $\mathrm{P} / \mathrm{B}$ ratio) are linked to the stock price in the following year. Analyzes use multiple regression by connecting EPS, PBV, to the stock price per year, over a period of 5 years, over a period of 10 years, and per industry sector. 


\section{Result and Analyses}

Fig. 1 shows the accounting data of price to earnings ratio and price to book value ratio of the firms listed in Indonesian Stock Index movement over the period 2007-2016. From the figure it can be observed that price to earnings ratio and price to book value ratio fluctuated but the stock index tend to growth. It can be predicted that in general stock prices are not affected by the movement of accounting data of price to earnings ratio and price to book value ratio.

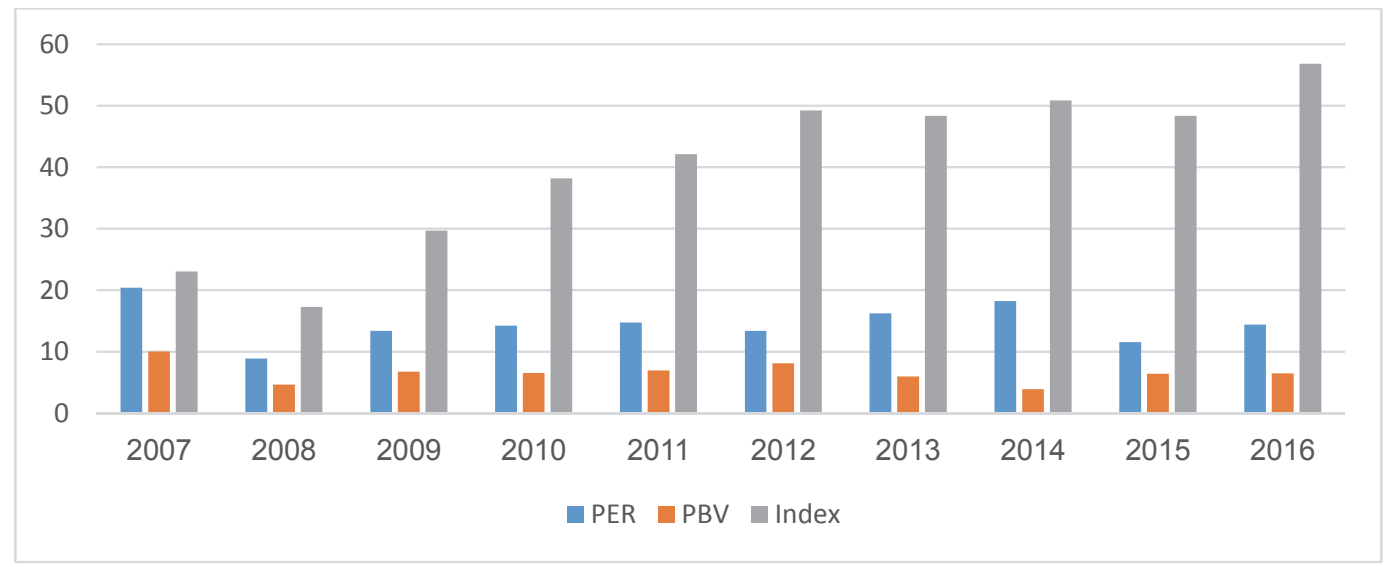

Fig. 1. Accounting Data and Indonesian Stock Index

The result of linear multi regression analyzed of data from 218 firms at Indonesian Stock Exchanges as sample with the statistical results are shown in Table 1 and Table 2.

Table 1

Statistical Analyses Result of Year 2007-2011

\begin{tabular}{|c|c|c|c|c|c|}
\hline Statistics & 2007 & 2008 & 2009 & 2010 & 2011 \\
\hline $\mathrm{N}$ & 218 & 218 & 218 & 218 & 218 \\
\hline $\mathrm{R}$ square & 0.034 & 0.06 & 0.075 & 0.133 & 0.012 \\
\hline Std Error Estimate & 2201.45 & 2409.25 & 4328.53 & 4987.90 & 5443.91 \\
\hline $\mathrm{F}$ & 3.767 & 6.807 & 8.739 & 16.548 & 1.303 \\
\hline Significance & $.025 \mathrm{~b}$ & $.001 \mathrm{~b}$ & $.000 \mathrm{~b}$ & $.000 \mathrm{~b}$ & $.274 b$ \\
\hline PER Coefficient & $?$ & $?$ & $?$ & $?$ & $?$ \\
\hline PER Significance & 0.172 & 0.359 & 0.934 & 0.814 & 0.701 \\
\hline PBV Coefficient & + & + & + & + & ? \\
\hline PBV Significance & 0.007 & 0 & 0 & 0 & 0.117 \\
\hline
\end{tabular}

Predictors: Stock Price

At $95 \%$ Confident Level

Table 1 shows that at $95 \%$ confident level price to earnings ratio has no effect on stock Price when the level of significance is five percent. Price to book value ratio in the year 2007-2010 are $<0.05$ with $t$ value with positive sign $(+)$ and $0.117>0.05$ for the year 2011 . It means that Price to book value ratio has positive effect on stock prices for the year 2007-2010 but has no effect for year 2011. However, with R-Square values of $0.034,0.06,0.075,0.133$ for the years 2007 to 2010 respectively, the model can predict the stock price poorly. Stock prices are affected by a lot of other factors other than EPS and BVS which can explain higher portion effect on stock prices. On other hand, the standard error estimates indicate that the model cannot explain the effect of EPS and P/B to stock prices, properly. Table 2 shows the level of price to earnings ratio has no effect on stock Price when the level of significance is five percent. Price to book value ratios of all years in period 2012-2016 are all significance $<0.05$ with $t$ the coefficient of positive sign $(+)$. It means that price to book value ratio has positive effect on stock prices for each year during 2012-2016. Nevertheless, with R-Square of 0.146, 0.145, 0.153, 0.168, and 0.171 for the years 2012 to 2016 respectively, the model can poorly predict the stock price. Stock prices are affected by a lot of other factors other than EPS and BVS which can explain higher portion effect on stock prices. In comparison with years 2007-2011, the R-Square values of all years of 2012-2016 are all higher than of 2007-2011. It means that after 2011 accounting data including PER and PBV can better 
explain the stock prices. On the other hand, the standard error estimates which are very high more than 4500 , indicate that the model cannot explain well the effect of EPS and BVS to stock prices.

Table 2

Statistical Analyses Result of Year 2012-2016

\begin{tabular}{lcccccc}
\hline Statistics & 2012 & 2013 & 2014 & 2015 & 2016 \\
\hline N & 218 & 218 & 218 & 218 & 218 \\
R square & 0.146 & 0.145 & 0.153 & 0.168 & 0.171 \\
Std. Error Estimate & 4538.45 & 5659.83 & 4855.41 & 5446.15 & 6271.81 \\
F & 18.334 & 18.209 & 19.48 & 21.659 & 22.235 \\
Significance & $.000 \mathrm{~b}$ & $.000 \mathrm{~b}$ & $.000 \mathrm{~b}$ & $.000 \mathrm{~b}$ & $.000 \mathrm{~b}$ \\
P/E Coefficient & $?$ & $?$ & $?$ & $?$ & $?$ \\
P/E Significance & 0.469 & 0.494 & 0.332 & 0.287 & 0.974 \\
P/B Coefficient & + & + & + & + & + \\
P/B Significance & 0 & 0 & 0 & 0 & 0 \\
\hline Predicis
\end{tabular}

Predictors: Stock Price

At $95 \%$ Confident Level

Table 3 shows that earnings ratio has no effect on stock price for the period of 2007-2011, 2012-2016, and 2007-2016 when the level of significance is five percent. Price to book value ratio in for the period of 2007-2011, 2012-2016, and 2007-2016 are all significance $<0.05$ with $t$ the coefficient of positive sign $(+)$. It means that price to book value ratio has positive effect on stock prices for all periods. However, with R-Square values of 0.022, 0.152, and 0.072 for the period of 2007-2011, 2012-2016, and 20072016 in respectively, the model can poorly predict the stock price. Stock prices are affected by a lot of other factors other than EPS and BVS which can explain higher portion effect on stock prices.

Table 3

Statistical Analyses Result of period 2007-2011, 2012-2016, and 2017-2016

\begin{tabular}{lccc}
\hline Statistics & $2007-2011$ & $2012-2016$ & $2007-2016$ \\
\hline N & 1090 & 1090 & 2180 \\
R square & 0.022 & 0.152 & 0.072 \\
Std Error Estimate & 4201.18 & 5381.73 & 4940.05 \\
F & 12.29 & 97.47 & 84.308 \\
Significance & $.000 \mathrm{~b}$ & $.000 \mathrm{~b}$ & $.000 \mathrm{~b}$ \\
P/E Coefficient & $?$ & $?$ & $?$ \\
P/E Significance & 0.652 & 0.642 & 0.505 \\
P/B Coefficient & + & + & + \\
P/B Significance & 0 & 0 & 0 \\
\hline PF
\end{tabular}

Predictors: Stock Price

At $95 \%$ Confident Level

Table 4

Statistical Analyses Result of Industry Sectors during 2007-2016

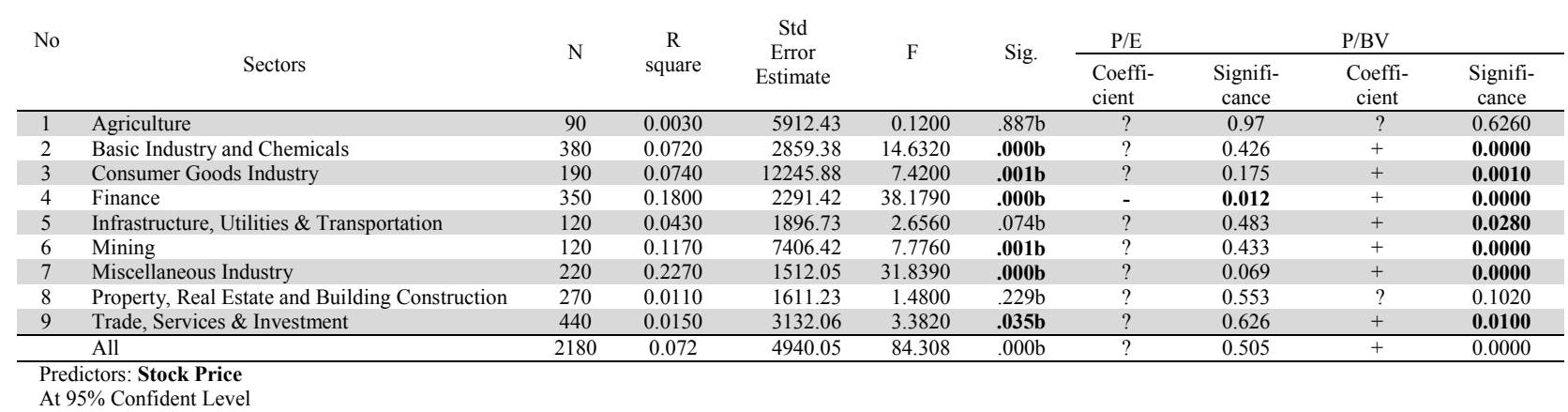

Table 4 contains statistical analyses of 9 (nine) Industry Sectors during 2007-2016 at 95\% confident level. The result indicates that only in Finance sector price to earnings ratio had negative effect on stock Price with the significance $<0.05$ with $t$ negative sign (-). Price to book value ratio of most sectors except for Agriculture and Property, Real Estate and Building Construction are all significance $<0.05$ with $t$ the coefficient of positive sign $(+)$. It means that price to book value ratio has positive effect on stock prices 
for all periods. Again with R-Square is very small and the standard error estimates is very high, this model fails to predict the relationship of EPS and BVS on stock prices in the industry sector.

\section{Conclusion}

This study has examined the accountability of the information price to earnings ratio ( $\mathrm{P} / \mathrm{E}$ ratio) and price to book value ratio (P/B ratio) for predicting the stock price movements during the period of 2007-2016, 2007-2011, 2012-2016, and for the period of 2007-2016 for firms listed on Indonesian Stock Exchange.

The results show that price to earnings ratio ( $\mathrm{P} / \mathrm{E}$ ratio) had no effect on stock prices for each year and also in all period, but price to book value ratio (P/B ratio) had positive effect on stock prices. It means that the higher the stock price to book value ratio (P/B ratio), the higher the stock price. When the stock price to book value ratio $(\mathrm{P} / \mathrm{B}$ ratio) is higher the stock price is considered more expensive for the investors. Investors who will buy the stocks must seek the stock with the lower price to book value ratio $(\mathrm{P} / \mathrm{B}$ ratio) to get potential gains. But the higher the book value ratio $(\mathrm{P} / \mathrm{B}$ ratio) is, the better the performance of the stocks. This study also revealed that price to book value ratio (P/B ratio) in industry sectors; including Basic Industry and Chemicals; Consumer Goods; Finance; Infrastructure; Utilities \& Transportation; Mining; Miscellaneous Industry; and Trade, Services \& Investment had positive effects on stock prices in the industry, but this effect did not occur in the Agriculture \& Property and Real Estate \& Building Construction industry.

Although the results of the study indicate that price to book value ratio ( $\mathrm{P} / \mathrm{B}$ ratio) had positive effect on stock prices, but the investors and other stock market members such as securities companies, stock market analysts, and manager of the firms should not use only price to book value ratio ( $\mathrm{P} / \mathrm{B}$ ratio) when they predict the stock prices movements.

\section{References}

Alfaraih, M., \& Alanezi, F. (2011). The usefulness of earnings and book value for equity valuation to Kuwait stock exchange participants. International Business \& Economics Research Journal, 10(1), 73-89.

Allen, D.E., \& Yang, W. (2003). Variation of Australian share prices due to fundamental and non-fundamental innovations. International Journal of Business Studies, 11(1), 1-24.

Almumani, M.A. (2014). Determinants of equity share prices of the listed banks in Amman stock exchange. Quantitative approach. International Journal of Business and Social Science, 5(1).

Basu, S. (1977). Investment performance of common stocks in relation to their price-earning ratios: A test of the efficient market hypothesis. The Journal of Finance, 32, 663-682.

Becchetti, L., \& Di Giacomo, S. (2007). Deviations from Fundamentals in US and EU Stock Markets: A Comparative Analysis. The European Journal of Finance, 13(3), 195-226.

Bisen, V., \& Pandey, M. (2013). Testing Efficient Market Hypothesis (EMH) in Current Indian Stock Market. Journal of Commerce and Management Thought, 4(4), 792.

Block, F. E. (1964). A study of the price to book relationship. Financial Analysts Journal, 20(5), 108117.

Bodie, Z., Kane, A., \& Marcus, A.J. (2005). Investment. Six Edition, McGraw Hill Companies Inc., New York, USA

Chambers, R. J. (1972). Stock Market Prices and Accounting Research. Abacus, Gower Press, Melbourne.

Das, N., \& Pattanayak, J. K. (2013). The effect of fundamental factors on Indian stock market: a case study of Sensex and nifty. IUP Journal of Applied Finance, 19(2), 84.

Dawar, V. (2014). Earnings persistence and stock prices: Empirical evidence from an emerging market. Journal of Financial Reporting and Accounting, 12(2), 117-134.

Indonesia Stock Exchange, IDX Fact Book. https://www.idx.co.id/Portals/0/StaticData/Publication/FactBook/FileDownload/

Indrayono, Y. (2011). Disposition effect terhadap hubungan antara nilai fundamental dan harga saham pada periode krisis finansial. Jurnal Keuangan dan Perbankan, 15(3), 315-326 
Kahneman, D., \& Tversky, A. (1979). Prospect theory: An analysis of decision under risk. Econometrica, 47(2), 263-292.

Khanna, M. (2014). Value Relevance of Accounting Information: An Empirical Study of Selected Indian Firms. International Journal of Scientific and Research Publications, 4(10).

Kwon, G.-J. (2009). The value relevance of book values, earnings and cash flows: evidence from Korea. International journal of business and management, 4(10), 28-42.

Lo, W.-C., \& Lin, K.-J. (2005). A review of the effects of investor sentiment on financial markets: Implications for investors. International journal of Management, 22(4), 708.

Munir, Q., Ching, K. S., Furouka, F., \& Mansur, K. (2012). The efficient market hypothesis revisited: Evidence from the five small open ASEAN stock markets. The Singapore Economic Review, 57(03), 1250021.

Nezlobin, A., Rajan, M. V., \& Reichelstein, S. (2016). Structural properties of the price-to-earnings and price-to-book ratios. Review of Accounting Studies, 21(2), 438-472.

De Pena, F. J., Forner, C., \& López-Espinosa, G. (2011). Fundamentals and the Origin of Fama-French Factors: The Case of the Spanish Market. Finance a Uver: Czech Journal of Economics \& Finance, 61(1).

Ozlen, S. (2014). The effect of company fundamentals on stock values. European Researcher, (3-2), 595-602.

Papadaki, A., \& Siougle, G. (2007). Value relevance of price, earnings and book values in the Athens Stock Exchange. Managerial Finance, 33(5), 309-320.

Penman, S., \& Reggiani, F. (2013). Returns to buying earnings and book value: Accounting for growth and risk. Review of Accounting Studies, 18(4), 1021-1049.

Rizky, Y. (2015). The Effect of The Fed's Quantitative Easing Policy on the Performance of Listed Companies and the Banking Sector in Indonesia. Australasian Accounting, Business and Finance Journal, 9(4), 71-81.

Shefrin, H., \& Statman, M. (1985). The disposition to sell winners too early and ride losers too long: Theory and evidence. The Journal of finance, 40(3), 777-790.

Shiller, R. J. (1981). Do stock prices move too much to be justified by subsequent changes in dividends?. American Economic Review, 71, 421-436

Vijitha, P., \& Nimalathasan, B. (2014). Value relevance of accounting information and share price: A study of listed manufacturing companies in Sri Lanka. Merit Research Journal of Business and Management, 2(1), 1-6.

Yahoo Finance, https://finance.yahoo.com/

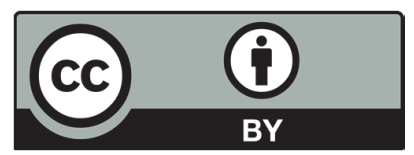

C 2019 by the authors; licensee Growing Science, Canada. This is an open access article distributed under the terms and conditions of the Creative Commons Attribution (CCBY) license (http://creativecommons.org/licenses/by/4.0/). 